\title{
Integrasi Konten dan Konteks Budaya Lokal Etnis Ngada dalam Bahan Ajar Multilingual untuk Pembelajaran Siswa Sekolah
} Dasar

\section{Lidvina Wero ${ }^{1}$, Dek Ngurah Laba Laksana ${ }^{2}$, Yosefina Uge Lawe ${ }^{3}$}

1,2,3Program Studi PGSD STKIP Citra Bakti, Bajawa, Indonesia

\section{ART ICLE I N F O}

\section{Article history:}

Received August 03, 2021

Revised August 04, 2021

Accepted September 30, 2021

Available online October 25, 2021

\section{Kata Kunci:}

Pembelajaran Multilingual, Konten Dan Konteks Budaya

\section{Keywords:}

Multilingual Instructional, Content and Context Ngada Culture

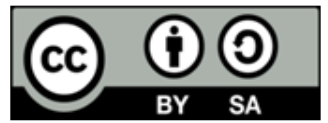

This is an open access article under the CC BY-SA license.

Copyright $@ 2021$ by Author. Published by Universitas Pendidikan Ganesha.

\begin{abstract}
A B S T R A K
Ketersediaan bahan ajar yang kontekstual penting untuk disediakan terutama sumber belajar berbasis budaya lokal setempat. Penelitian ini bertujuan untuk mengembangkan dan menghasilkan bahan ajar cetak multilingual berbasis konten dan konteks budaya lokal etnis Ngada. Subjek uji coba penelitian pengembangan ini adalah guru SD, dosen dan siswa. Objek yang diteliti adalah konten dan konteks budaya lokal etnis Ngada yang bisa diintegrasikan dengan materi SD. Bahan ajar multilingual berbasis konten dan konteks budaya lokal etnis Ngada ini dikembangkan menggunakan model ADDIE. Model ADDIE terdiri atas lima langkah, yakni analyze, design, development, implementation, dan evaluation. Bahan ajar multilingual yang telah dikembangkan dalam penelitian ini diuji dan dianalisis oleh beberapa ahli. Hasil uji coba oleh ahli adalah sebagai berikut. Uji coba ahli materi berada pada kategori "sangat baik" dengan nilai rata-rata 4,7, Uji coba untuk ahli bahasa Indonesia pada kategori " sangat baik" dengan nilai ratarata 4,0, Uji coba oleh ahli bahasa daerah berada pada kategori "baik" dengan nilai rata-rata 4,0, Uji coba ahli bahasa Inggris pada kategori "sangat baik" dengan nilai rata-rata 4,2 , Uji coba oleh ahli desain berada pada kategori "sangat baik" dengan rata-rata 4,1, Uji kelayakan penggunaan pada kategori "sangat baik" dengan nilai rata-rata 4,2. Berdasarkan hasil pengujian terhadap beberapa ahli tersebut di atas, dapat diambil kesimpulan bahwa bahan ajar multilingual berbasis budaya lokal etnis Ngada untuk siswa kelas II Sekolah Dasar layak dan siap untuk digunakan.
\end{abstract}

\section{A B S TR A C T}

The availability of contextual teaching materials is important to provide, especially learning resources based on local local culture. This study aims to develop and produce multilingual printed teaching materials based on the content and context of the local Ngada ethnic culture. The trial subjects of this development research were elementary school teachers, lecturers and students. The object under study is the content and context of the local Ngada ethnic culture that can be integrated with elementary school materials. This multilingual teaching material based on the content and context of the local Ngada ethnic culture was developed using the ADDIE model. The ADDIE model consists of five steps, namely analyze, design, development, implementation, and evaluation. The multilingual teaching materials that have been developed in this study were tested and analyzed by several experts. The results of trials by experts are as follows. The material expert test was in the "very good" category with an average score of 4.7, the test for Indonesian language experts was in the "very good" category with an average score of 4.0, the regional linguist test was in the category "good" with an average score of 4.0, Testing by English experts in the "very good" category with an average value of 4.2, Testing by design experts in the "very good" category with an average of 4, 1 , Feasibility test of use in the "very good" category with an average value of 4.2. Based on the results of testing on several experts mentioned above, it can be concluded that multilingual teaching materials based on local Ngada ethnic culture for grade II elementary school students are feasible and ready to be used.

\section{PENDAHULUAN}

Sistem Pendidikan Nasional Nomor 20 Tahun 2003, pendidikan merupakan suatu usaha yang dilakukan secara sadar dan terencana untuk mewujudkan suasana dan proses pembelajaran agar peserta didik secara aktif mampu mengembangkan potensi yang ada di dalam dirinya untuk memiliki kekuatan spiritual keagamaan, kepribadian yang baik, pengendalian diri, berakhlak mulia, kecerdasan, dan keterampilan yang diperlukan oleh 
dirinya dan masyarakat (Muhamad Nova, 2017; Pitaloka et al., 2021). Pendidikan saat ini berkembang sangat cepat seiring perkembangan ilmu pengetahuan dan teknologi (Putra et al., 2017). Kebutuhan masyarakat akan pendidikan bertambah dan pendidikan menjadi prioritas utama dalam era globalisasi seperti saat ini. Pendidikan memiliki pengaruh yang sangat penting dalam suatu kehidupan baik secara kelompok maupun individu. Dimana setiap individu berhak mendapatkannya dan diharapkan untuk selalu berkembang didalamnya (Kitao dan Kitao, 2018). Perkembangan ini diharapkan mampu menghadapi segala perubahan dan permasalahan dengan sikap terbuka serta pendekatan-pendekatan yang kreatif tanpa harus kehilangan identitas dirinya (Awe \& Moma, 2021; Subhan et al., 2017). Dalam lingkup pendidikan formal peran pendidik menjadi sangat penting bukan hanya sebagai pentransfer pengetahuan kepada siswa namun juga yang mampu menciptakan pengalaman positif yang bermanfaat jangka panjang (Hapsari et al., 2021; Jannah et al., 2021) Oleh karena itu, dalam proses pembelajaran guru harus memiliki kreatifitas dan inovasi tinggi untuk menghasilkan proses peembelajaran yang lebih bermanfaat. Kreatifitas yang dilakukan guru dalam proses pembelajaran diantaranya menggunakan sumber, metode dan media pembelajaran yang bervariatif yang sesuai dengan materi dan kebutuhan siswa agar tujuan pembelajaran dapat tercapai dengan maksimal (Fitriyani et al., 2021; Sarini \& Selamet, 2019). Pendidik juga harus mampu menguasai banyak kompetensi keguruan agar dapat dimanfaatkan dalam proses pembelajaran dan mengatasi masalah atau kendala yang tiba-tiba muncul dalam proses pembelajaran (Mustaqim \& Wijayanti, 2019).

Pada kenyataannya sistem pendidikan di Indonesia masih banyak mengalami kendala. Mutu pendidikan yang rendah merupakan masalah yang dihadapi dalam dunia pendidikan (Sudarsana, 2016). Rendahnya mutu pendidikan dapat disebabkan oleh proses pembelajaran yang belum efektif (Sudrajat et al., 2021). Banyak guru yang lebih sering menggunakan bahan ajar cetak yang disiapkan pemerintah pusat yang cenderung membuat siswa Sekolah Dasar sulit menghubungkan materi dengan kehidupan sehari-hari siswa yang kondisi lingkungannya berbeda dengan kondisi lingkungan yang ada pada bahan ajar cetak yang telah disiapkan pemerintah. Bahan ajar yang dibuat guru semestinya dibuat sebaik mungkin sehingga dapat menarik perhatian siswa untuk belajar juga memotivasi belajar siswa sehingga proses pembelajaran dapat lebih bermakna. Berdasarkan hal tersebut, maka guru harus memperhatikan strategi belajar mengajar, sehingga tercipta situasi yang efektif dan efisien sesuai dengan pokok bahasan materi pelajaran yang akan diajarkan dan memperhatikan perbedaan karakteritik peserta didik dalam proses pembelajaran. Kemampuan guru dalam menyiapkan bahan ajar yang sesuai dengan kebutuhan siswa, kondisi lingkungan, dan tuntutan zaman juga sangat diperlukan (Nugrahani, 2017; Sarini \& Selamet, 2019). Guru harus mampu menyiapkan bahan ajar sendiri tanpa harus mengambil bahan ajar yang sudah dibuat orang lain yang mungkin kurang tepat dengan keadaan lingkungan belajar siswa(Hutama, 2016; Krismawati, 2019). Sekitar 95\% guru di Kabupaten Ngada masih menggunakan bahan ajar cetak yang sudah jadi seperti buku tematik yang telah disediakan oleh pemerintah atau LKS yang merupakan hasil dari suatu penerbit yang mungkin tidak sesuai dengan lingkungan di mana siswa tersebut belajar (Lawe, Noge, Wede, et al., 2021) Unsur budaya lokal seperti alat musik tradisional, cerita rakyat, ritual adat, situs-situs budaya serta hewan peliharaan ini cocok dimasukan ke dalam bahan ajar siswa, khususnya siswa di sekolah dasar (Baka et al., 2018; Isnaini et al., 2018; Lawe, Noge, Rato, et al., 2021).

Budaya lokal perlu diintegrasikan dengan pembelajaran tematik di SD karena salah satu ciri kegiatan pembelajaran tematik adalah fleksibel dimana guru dapat mengaitkan materi pelajaran dengan tema yang ada di lingkungan tempat tinggal peserta didik (Lawe et al., 2019; Prayogi et al., 2019). Pembelajaran berbasis budaya bukan sekedar menstransfer atau menyampaikan budaya atau perwujudan budaya, tetapi menggunakan budaya untuk menjadikan siswa mampu menciptakan makna, menembus batas imajinasi, dan kreativitas untuk mencapai pemahaman yang mendalam tentang materi subyek yang dipelajarinya (Riwu et al., 2018; Sarini \& Selamet, 2019). Untuk itu perlu dilakukan upaya pengembangan bahan ajar yang mengutamakan unsur kearifan lokal khususnya budaya lokal masyarakat Ngada yang memiliki ragam budaya yang sangat cocok dimasukkan dalam pembelajaran di sekolah dasar (Kurniawan, 2019; Laksana et al., 2016).

Pengembangan bahan ajar sudah selayaknya merupakan suatu kemampuan yang seharusnya dapat dikuasai dan terus ditingkatkan oleh setiap guru. Jika kemampuan mengembangkan bahan ajar yang bervariasi tidak dimiliki seorang guru maka guru akan terjebak pada situasi pembelajaran yang monoton dan cenderung membosankan bagi siswa(Saidah et al., 2014; Suplemen et al., 2017). Bahan ajar yang dibuat guru harus memperhatikan lingkungan sosial siswa, adat istiadat dan kebiasaan-kebiasaan dalam kehidupan sehari-hari siswa seperti budaya local (Lawe et al., 2019). Guru harus mampu memanfaatkan kebiasaan dalam lingkungan siswa dalam mencapai tujuan pembelajaran. Misalnya, dengan menghubungkan atau mengintegrasikan kehidupan sosial siswa kedalam materi pembelajaran. Guru bisa menggunakan contoh-contoh konkret kebiasaan dalam lingkungan sosial siswa untuk menjelaskan suatu materi pembelajaran (Aisyah, 2018; Nuraini, 2019). Guru juga mampu menghubungkan materi pembelajaran bukan hanya dengan kondisi lingkungan terdekat siwa namun juga dapat diintegrasikan dengan perkembangan dan tuntutan zaman. Sehingga siswa tidak hanya belajar dari hal-hal yang sederhana dalam kehidupannya namun bisa mempersiapkan diri menghadapi tuntutan globalisasi. Salah satu tuntutan globalisasi yang sangat nyata adalah penggunaan bahasa Inggris sebagai bahasa komunikasi internasional (Liyana \& Kurniawan, 2019). 
Bahan ajar multilingual merupakan bahan ajar yang mengintegrasikan tiga bahasa. Bahasa yang digunakan adalah bahasa Indonesia sebagai bahasa nasional, bahasa daerah sebagai bahasa penunjang juga sebagai perwujudan kearifan lokal, dan bahasa Inggris sebagai bahasa ketiga dan sudah digunakan secara global. Bahasa Inggris sendiri perlu diterapkan dalam pembelajaran di sekolah dasar karena dapat memberikan pengalaman baru bagi peserta didik dan merangsang serta meningkatkan kemampuan siswa dalam berpikir dan berkomunikasi dengan lawan bicara yang berbeda (Gimatdinova, 2018a; Maili, 2018). Bahasa Inggris juga sudah ditetapkan sebagai bahasa komunikasi internasional dan hampir semua sistem di era globalisasi ini menggunakan bahasa Inggris (Liyana \& Kurniawan, 2019; Priyastuti et al., 2020). Pembiasaan menggunakan bahasa Inggris sederhana yang diterapkan sejak dini pada siswa sekolah dasar dapat mempersiapkan siswa menghadapi tuntutan zaman yang semakin meningkat (Ghasemi \& Hashemi, 2011; Maili, 2018). Sejauh ini bahan ajar berbasis budaya telah dikembangkan. Bahan ajar yang telah berhasil dikembangkan antara lain LKS SD berbasis budaya Ngada, multimedia berbasis budaya, dan buku elektronik SD berbasis budaya Ngada (Laksana et al., 2016; Muga \& D.N.L., 2017; Riwu et al., 2018). Pengembangan bahan ajar berbasis budaya local pada pembelajaran tematik (Divan, 2018). Namun demikian, ketersediaan bahan ajar berbasis budaya masih perlu ditingkatkan sesuai dengan karakteristik pembelajaran di wilayah tersebut. Tujuan penelitian ini adalah menciptakan bahan ajar yang terintegrasi konten dan kontek budaya lokal Ngada serta kualitas bahan ajar yang dihasilkan.

\section{METODE}

Jenis penelitian dalam penelitian ini yaitu penelitian pengembangan. Pengembangan bahan ajar multilingual ini menggunakan model pengembangan ADDIE (Dick \& Carey, 2009). Prosedur pengembangan model ADDIE terdiri atas lima tahapan yaitu Analyze (Analisis); Tahap analisis yang dilakukan mencakup tiga hal penting yaitu analisis kebutuhan, analisis kurikulum, dan analisis karakteristik peserta didik kelas 2 Sekolah Dasar. Design (Perancangan), pada tahap ini mulai dirancang bahan ajar yang akan dikembangkan sesuai dengan hasil analisis yang dilakukan sebelumnya. Development (Pengembangan). Tahap development merupakan tahap realisasi produk. Dalam tahap ini pengembangan bahan ajar dilakukan sesuai dengan perancangan. Implementation (Implementasi). Tahap implementation hanya sampai pada validator ahli yang direkomendasikan untuk menilai produk bahan ajar yang sudah dikembangkan. Evaluation (Evaluasi). Pada tahap evaluasi ini, melakuan revisi yang terakhir kalinya terhadap bahan ajar yang dikembangkan atas dasar informasi yang diperoleh dari instrumen penilaian yang dinilai oleh setiap validator/ahli. Produk yang dihasilkan berupa bahan ajar multilingual berbasis konten dan konteks budaya lokal etnis Ngada pada tema pengalamanku untuk siswa kelas 2 SD.

Uji coba produk ini menggunakan instrumen dalam bentuk angket yang telah disusun. Instrumen yang berupa angket dinilai oleh ahli konten/materi pada kelayakan isi dari materi ajar, ahli desain pada kelayakan desain produk bahan ajar yang dikembangkan, ahli bahasa pada kesesuaian penggunaan bahasa. Subjek uji coba dalam penelitian ini antara lain: guru kelas 2 SD sebagai ahli konten/materi yang diambil dari SDI Rutosoro, dosen STKIP Citra Bakti sebagai ahli bahasa Inggris, guru SMP Citra Bakti sebagai ahli bahasa Indonesia, seorang tokoh penulis buku bahasa daerah Bajawa (budayawan) sebagai ahli bahasa daerah, dosen Universitas PGRI Kediri sebagai ahli desain pembelajaran, dan siswa kelas 2 SD sebagai calon pengguna produk. Data yang diperoleh didalam penelitian ini yaitu: (1) data isi dari materi ajar dalam tema pengalamanku yang dapat diintegrasikan dengan konten dan konteks budaya lokal etnis Ngada, data karakteristik budaya lokal etnis Ngada sebagai konten dan konteks terhadap bahan ajar multilingual pada tema benda, hewan dan tanaman di sekitarku, data kualitas bahan ajar multilingual ini akan dilihat dari isi, penyajian, kebahasaan dan kelayakan penggunaan. Metode yang diterapkan selama proses mengumpulkan data yaitu: 1) metode observasi. Metode wawancara. metode pencatatan dokumen, Instrumen pengumpulan data dalam penelitian pengembangan bahan ajar multilingual ini adalah berbentuk angket yang berpatok pada penilaian Badan Standarisasi Nasional Pendidikan (BSNP), di antaranya yaitu komponen isi dan kegrafikan.

Data yang sudah dikumpulkan dari hasil penelitian ini dianalisis secara deskriptif. Data tentang kualitas bahan ajar multilingual hasil review ahli dianalisis secara deskriptif untuk menganalisis data hasil review ahli materi, ahli desain pembelajaran dan ahli bahasa. Teknik analisis data ini dilakukan dengan mengelompokan informasi dari data kualitatif yang berupa saran, kritik, masukan, dan tanggapan yang terdapat pada angket. Data mengenai kualitas bahan ajar multilingual berisi budaya lokal hasil uji coba produk dianalisis melalui konversi skor yang diperoleh dari lembar kuisioner. Pengubahan hasil penilaian dari setiap Ahli, berawal dari bentuk kualitatif ke bentuk kuantitatif dengan menggunakan skala 5 sebagai berikut: skor 1 Sangat Kurang (SK), skor 2 Kurang (K), skor 3 Cukup (C), skor 4 Baik (B), dan skor 5 Sangat Baik (SB). Produk yang dikembangkan dikatakan memiliki derajat validitas atau kualitas yang baik jika minimal kriteria validitas yang dicapai adalah baik. 


\section{HASIL DAN PEMBAHASAN}

Hasil

Pengembangan produk bahan ajar yang multilingual yang dikembangkan ini menggunakan model pengembangan ADDIE. Tahap Analyze, pada tahap analisis ini menganalisis pentingnya mengembangkan bahan ajar juga menganalisis syarat dan kelayakan pengembangan. Yang penulis lakukan pada tahap ini meliputi tiga hal yakni menganalisis kebutuhan, menganalisis kurikulum, juga menganalisis karakteristik siswa. Tahap-tahap analisis yang peneliti lakukan dalam pengembangan bahan ajar ini yakni analisis kebutuhan. Hal pertama yang dilakukan pada tahap ini adalah menganalisis keadaan bahan ajar sebagai informasi pokok dalam pembelajaran juga tersedianya bahan ajar yang dapat mendukung pelaksanaan suatu kegiatan pembelajaran. Tahap ini peneliti menentukan bahan ajar yang penting dan yang bisa dikembangkan untuk membantu siswa dalam proses pembelajaran. Analisis kurikulum dilakukan dengan melihat karakteristik kurikulum yang sedang dipakai pada suatu sekolah. Tahap ini lakukan supaya pengembangan yang dilakukan dapat disesesuaikan dengan kurikulum yang berlaku di sekolah. Selanjutnya perumusan indikator-indikator pembelajaran yang ingin dicapai dengan mengkaji kompetensi dasar. Analisis karakteristik siswa. Tahap ini dilakukan agar mampu melihat sikap siswa saat mengikuti proses pembelajaran. Tahap ini juga dilakukan agar produk yang peneliti kembangkan dapat sesuai dengan karakterisitik siswa.

Tahap desain atau perancangan dalam menyusun bahan ajar ini diawali dengan menentukan hal-hal pokok yang diperlukan dalam bahan ajar seperti pemetaan Kompetensi Inti, Kompetensi Dasar, Indikator dan Tujuan Pembelajaran di setiap subtema dan pembelajaran, kerangka bahan ajar, dan mengumpulkan bahan acuan yang dimanfaatkan dalam pengembangan materi dari bahan ajar. Peneliti juga mengumpulkan gambargambar yang berkaitan dengan materi ajar untuk dimasukan dalam bahan ajar yang dikembangkan. Tahap development, tahap pengembangan merupakan tahap realisasi produk. Pada tahap ini peneliti melakukan pengembangan produk bahan ajar multilingual dengan melalui beberapa tahap yaitu: melakukan pengembangan produk bahasa Indonesia. Peneliti menyusun buku bahasa Indonesia dengan memasukan materi ajar berbasis konten dan konteks budaya lokal etnis Ngada yang dilengkapi dengan gambar sebagai komponen penjelas dari materi ajar, keterangan gambar beserta sumber gambar. Pada pengembangan tahap ini peneliti melakukan pengembangan bahan ajar berpatokan pada pedoman buku guru dan buku siswa tema 5 untuk siswa SD kelas 2 revisi 2017. Melakukan pengembangan bahasa daerah. Pada tahap ini menerjemahkan buku bahasa Indonesia yang sudah disusun diterjemahkan ke dalam bentuk bahasa daerah Bajawa dan melakukan pengembangan produk bahasa Inggris. Pada tahap menerjemahkan bahan ajar bahasa Indonesia yang sudah disusun dan diterjemahkan ke dalam bentuk bahasa Inggris.

Hasil pengembangan bahan ajar multiligual berbasis konten dan konteks budaya lokal etnis Ngada yaitu halaman judul (Cover) merupakan tampilan dari buku tematik multilingual yang dikembangkan. Kata pengantar memuat ucapan syukur penulis kepada Tuhan Yang Maha Esa atas semua berkat dan bimbingan-Nya kepada penulis, semasa penulis. Tentang bahan ajar multilingual ini merupakan panduan yang dirancang sangat sederhana dan bertujuan untuk menyampaikan kepada guru dan siswa terkait komponen-komponen yang tercantum dalam isi bahan ajar. Daftar isi dibuat dengan tujuan mempermudahkan orang yang membaca atau pengguna produk untuk membuka setiap subtema dan halaman yang bakal mereka pelajari. Sub tema dibuat dengan tujuan memberikan gambaran awal dalam bentuk gambar dan tulisan untuk bagaimana mempelajari semua materi yang tercantum pada sub tema. Kompetensi dasar yang dipetakan dalam bahan ajar multilingual berbasis konten dan konteks budaya lokal etnis Ngada ini adalah tema 5 yaitu tema pengalamanku untuk siswa kelas 2 SD. Pemetaan KD subtema 1 yang terkandung pada bahan ajar multilingual ini memuat tentang sejumlah mata pelajaran yang menjadi fokus pembelajaran yaitu: Bahasa Indonesia, SBdP, PPKn dan Matematika. Materi yang terdapat dalam bahan ajar multilingual ini yaitu materi tema 5 yaitu "Pengalamanku" untuk siswa kelas 2 SD yang dipadukan dengan konten dan konteks budaya lokal etnis Ngada. Daftar pustaka berisi daftar referensi dan sumber-sumber yang membantu proses penyelesaian pengembangan bahan ajar multilingual ini. Tampilan produk hasi pengembangan disajikan pada Gambar 1. Selanjutnya dilakukan uji praktisi dari para ahli. Hasil penilaian untuk masing masing ahli disajikan seperti pada Tabel 1.

Berdasarkan hasil perhitungan rata-rata skor uji validitas diperoleh hasil bahwa rata-rata yang diperoleh dari segi materi secara keseluruhan yaitu 4,3 dengan kualifikasi sangat baik. Hasil perhitungan ahli bahasa indonesia yaitu 4,1 dengan kualifikasi sangat baik. Dilihat dari rata-rata skor dari segi ahli bahasa daerah dinyatakan baik dengan 3, 58. Dilihat dari rata-rata skor dari segi ahli bahasa inggris dinyatakan sangat baik dengan 4,15. Hasil rata-rata ahli desain diperoleh 4,45 dengan kriteria sangat baik Sementara itu, dari pengguna produk menyatakan bahwa bahan ajar ada pada kualifikasi sangat baik dengan rata-rata yaitu 4,18. Berdasarkan hasil tersebut bahan ajar multilingual berbasis konten dan konteks budaya lokal etnis Ngada dinyatakan valid dengan kualifikasi sangat baik. Pada tahap implementasi ini, uji coba produk pengembangan bahan ajar multilingual berbasis konten dan konteks budaya lokal etnis Ngada terhadap ahli konten/materi, ahli bahasa dan ahli desain bahan ajar dan calon pengguna produk. 

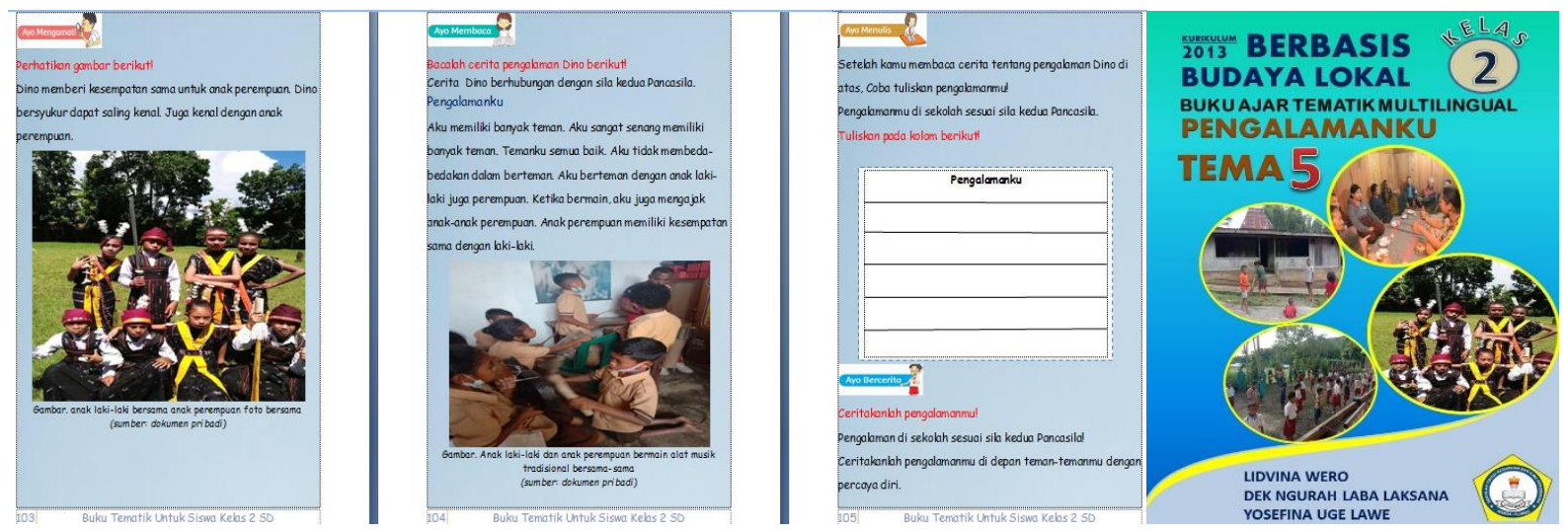

Gambar 1. Tampilan Halaman Depan dan Salah satu Isi dari Bahan Ajar

Tabel 1. Hasil Validasi Bahan Ajar Multilingual

\begin{tabular}{lcl}
\hline Ahli yang menilai & Rata-rata skor & Kriteria \\
\hline Ahli konten/materi & 4,3 & Sangat baik \\
Ahli bahasa Indonesia & 4,1 & Sangat baik \\
Ahli bahasa daerah & 3,58 & Baik \\
Ahli bahasa Inggris & 4,15 & Sangat baik \\
Ahli desain bahan ajar & 4,45 & Sangat baik \\
Pengguna Produk (Siswa Kelas II SD) & 4,18 & Sangat baik \\
\hline
\end{tabular}

Tahap evaluasi yaitu tahap yang dilakukan peneliti untuk merevisi setiap tahap-tahap pengembangan lainnya. Revisi tahap Analyze, Peneliti menganalisis kompetensi Dasar kelas 2 Sekolah Dasar pada tema "Pengalamanku". Setelah menganalisis Kompetensi Dasar, peneliti melakukan revisi berdasarkan komentar pembimbing I dan II. Hasil revisi pada tahap ini adalah lagu-lagu yang terdapat dalam lagu hendaknya menggunakan bahasa daerah atau memuat unsur budaya lokal dan harus menggunakan notasi angka terlebih dahulu. Tahap Design, menyusun draf bahan ajar multilingual berbasis konten dan konteks budaya lokal etnis Ngada. Berdasarkan hasil analisis yang dilaksanakan pada tahap sebelumnya. Komentar dan saran pembimbing I dan II dalam tahap ini yaitu gambar-gambar yang terdapat dalam bahan ajar yang dikembangkan harus bersifat kontekstual agar siswa mampu memahami materi pelajaran dengan baik. Revisi Tahap Development, Revisi tahap ini lebih kepada hasil uji coba pertama produk pengembangan ke beberapa validator/ahli.

Hasil revisi produk bahan ajar multilingual berdasarkan komentar/masukan maupun saran dari masingmasing validator/ahli dapat kita lihat pada penjelasan berikut. Revisi Hasil Uji Coba Ahli Konten/Materi. Penilaian yang diberikan oleh ahli konten/materi terhadap produk bahan ajar multilingual yang dikembangkan pada tahap ini yaitu, ahli konten/materi lebih menekankan pada penulisan teks percakapan yang terlalu panjang yang membuat siswa kelas 2 cenderung jenuh untuk membaca teks dan penggunaan istilah bahasa daerah yang harus dijelaskan maknanya dalam bahasa Indonesia. Revisi Hasil Uji Coba Ahli Bahasa. Penilaian yang diberikan oleh ahli bahasa terhadap produk bahan ajar multilingual yaitu revisi hasil uji coba ahli bahasa Indonesia. Penilaian yang diberikan oleh ahli bahasa Indonesia yaitu penggunaan huruf kapital, penggunaan tanda baca yang belum sesuai khususnya pada teks percakapan, dan penulisan cerita pengantar materi yng kuran dimengerti oleh peserta didik kelas 2 SD, revisi hasil uji coba ahli bahasa daerah. yaitu ketepatan penulisan bahasa daerah Bajawa yang belum sesuai serta pentingnya penggunaan tanda baca yang terdapat pada beberapa kata bahasa daerah Bajawa yang sesuai dengan cara penyebutannya, revisi hasil uji coba ahli bahasa Inggris. Penilaian hasil uji coba bahasa Inggris yaitu penggunaan kata dan kalimat yang belum sesuai dengan grammar dan juga penggunaan bahasa Inggris yang terlalu kompleks sehingga sulit dipahami siswa sekolah dasar kelas 2 . Revisi Hasil Uji Coba Ahli Desain Bahan Ajar. Penilaian yang diberikan oleh ahli desain pembelajaran terhadap produk bahan ajar multilingual yang dikembangkan pada tahap ini yaitu, ahli desain bahan ajar memberikan komentar terdapat beberapakesalahan dalam pengetikan.

\section{Pembahasan}

Berdasarkan uraian hasil penelitian di atas, tujuan penelitian ini adalah menciptakan bahan ajar cetak multilingual berbasis konten dan konteks budaya lokal Ngada. Bahan ajar cetak multilingual berbasis konten dan konteks budaya lokal etnis Ngada pada tema Pengalamanku untuk siswa kelas 2 Sekolah Dasar masuk pada kriteria baik. Hal tersebut dilihat dari beberapa aspek. Pertama, bahan ajar ini sesuai dengan karakteristik siswa kelas 2 Sekolah Dasar pada umumnya dan siswa kelas 2. bahan Penilaian dalam pengembangan produk ini 
adalah penilaian konten atau materi, penilaian daria aspek kebahasaan (bahasa Indonesia, bahasa daerah (bahasa Bajawa), bahasa Inggris), penilaian desain pembelajaran dan siswa sebagai calon pengguna produk. Bahan ajar ini dapat digunakan pada proses pembelajaran tematik. Pembelajaran tematik memiliki beberapa ciri ciri yang perlu diintegrasikan dalam sumber belajar (Onde et al., 2020). Ciri ciri tersebut antara lain berpusat pada anak, memberikan pengalaman langsung pada anak, pemisahan antar muatan pelajaran tidak begitu jelas, menyajikan konsep dari berbagai pelajaran dalam satu proses pembelajar, keterpaduan berbagai muatan pelajaran, dan hasil pembelajaran dapat berkembang sesuai dengan minat dan kebutuhan anak (Divan, 2018; Laksana et al., 2016). Oleh karena itu, bahan ajar yang telah dihasilkan ini adalah bahan ajar tematik, sebagai alternatif sumber belajar yang dibutuhkan oleh peserta didik. Bahan ajar tematik ini sesuai dengan karakteristik peserta didik, kontekstual, serta memberikan ruang dipelajari dalam berbagai Bahasa. edua, bahan ajar cetak multilingual berbasis konten dan konteks budaya lokal etnis Ngada pada tema Pengalamanku serta bahan ajar yang dikembangkan ini telah sesuai dengan karakteristik siswa Sekolah Dasar kelas II di Kabupaten Ngada khususnya daerah Bajawa karena bahan ajar yang dikembangkan berbasis konten dan konteks budaya lokal etnis Ngada kriteria validasi hasil uji coba produk sangat baik. Dilihat dari desain, bahan ajar ini sangat menarik dan dilengkapi dengan gambar konkret. Dengan adanya gambar yang konkret akan memberikan siswa belajar dengan bermakna (Nuraini, 2019; Setyowati \& Mawardi, 2018). Selain itu, bahan ajar disusun secara sistematis sehingga siswa lebih mudah untuk memahami. Bahan ajar merupakan segala bahan (baik informasi, alat maupun teks) yang disusun secara sistematis yang menampilkan sosok utuh dari kompetensi yang akan dikuasai oleh peserta didik yang digunakan dalam proses pembelajaran dengan tujuan perencanaan dan penelaahan implementasi pembelajaran (Kurniawan, 2019; Rizki \& Linuhung, 2017). Beberapa fungsi bahan ajar adalah pedoman bagi guru yang akan mengarahkan semua aktivitasnya dalam proses pembelajaran, sekaligus merupakan substansi kompetensi yang seharusnya diajarkan kepada siswa. Pedoman bagi siswa yang akan mengarahkan semua aktivitasnya dalam proses pembelajaran, sekaligus merupakan substansi kompetensi yang seharusnya dipelajari/dikuasainya. Dan alat evaluasi pencapaian/ penguasaan hasil pembelajaran.

Ketiga, multilingual merupakan penggunaan tiga bahasa sekaligus dalam proses pembelajaran. Pada pembelajaran multilingual siswa sekolah dasar multilingual menggunakan tiga bahasa yakni bahasa daerah, bahasa Indonesia, dan bahasa Inggris sebagai bahasa ketiga. Bahan ajar multilingual adalah seperangkat materi pembelajaran yang disusun secara runtut dan sistematis dalam tiga bahasa sekaligus serta menampilkan sosok utuh dari kompetensi yang akan dikuasai oleh siswa dalam kegiatan pembelajaran didalam kelas yang dikemas dalam bentuk bahan ajar cetak multilingual. Penggunaan bahasa daerah dalam bahan ajar multilingual juga bertujuan untuk mempertahankan salah satu warisan leluhur atau mempertahankan nilai budaya local (Divan, 2018; Rahman et al., 2019). Pentingnya bahan ajar berbasis mengandung muatan Bahasa Inggris sebagai Bahasa Intrenasional telah banyak diteliti. Bahasa Inggris sendiri perlu diterapkan dalam pembelajaran di sekolah dasar karena dapat memberikan pengalaman baru bagi peserta didik. Bahasa global ini juga dapat merangsang serta meningkatkan kemampuan siswa dalam berpikir dan berkomunikasi dengan lawan bicara yang berbeda (Ghasemi \& Hashemi, 2011; Gimatdinova, 2018b; Maili, 2018; Nasution \& Jazuli, 2020). Oleh karena itu, bahan ajar ini dapat diterapkan paro pembelajaran berbasis budaya merupakan pembelajaran yang mengintegrasikan budaya dalam proses pembelajaran serta salah satu bentuknya adalah menekankan belajar dengan budaya.

Hasil penelitian ini diperkuat dengan penelitian sebelumnya yang menyatakan bahan ajar yang dikembangkan sudah baik sehngga layak digunakan(Laksana et al., 2016). Temuan lain bahan ajarnya dapat meningkatkan mnat belajar (Lawe et al., 2019; Supramono, 2016) Penelitian lain yang relevan dengan penelitian pengembangan ini adalah penelitian yang dilakukan oleh Lawe (2019), hasil penelitian ini diuji oleh beberapa ahli dan siswa dan berada pada kriteria sangat baik sehingga layak digunakan untuk siswa Sekolah Dasar kelas IV di kabupaten Ngada. Pengembangan bahan ajar multilingual sudah banyak dilakukan. Hasil pengembangan menunjukkan bahwa bahan ajar multilingual layak untuk digunakan dengan berbagai variasi kriteria kualitas produk bahan ajar yang dihasilkan. Adanya bahan ajar ini dapat membantu guru dan siswa dalam proses pembelajaran khususnya pada materi.

\section{SIMPULAN}

Bahan ajar multilingual berbasis konten dan konteks budaya lokal Ngada. Bahan ajar cetak multilingual berbasis konten dan konteks budaya lokal etnis Ngada pada tema Pengalamanku untuk siswa kelas 2 Sekolah Dasar masuk pada kriteria baik. Bahan ajar ini sesuai dengan karakteristik siswa kelas 2 Sekolah Dasar. Kualitas bahan ajar inidiketahui dari hasil penilaian yang diberikan oleh ahli dan siswa sebagai pengguna produk.

\section{DAFTAR PUSTAKA}

Aisyah, E. N. (2018). Internalisasi Nilai Karakter Nasionalisme melalui Dongeng dan Tari (DORI) bagi Anak Usia Dini. Golden Age: Jurnal Pendidikan Anak Usia Dini, 2(2), 26-34. https://doi.org/10.29313/ga.v2i2.4293.

Awe, E. ., \& Moma, A. (2021). Pengembangan Bahan Ajar Multilingual Berbasis Konten dan Konteks Kudaya Lokal Etnis Ngada pada Tema Kegiatanku untuk Siswa Sekolah Dasar. Jurnal Ilmiah Pendidikan Citra Bakti, 
8(1), 53-67. https://doi.org/10.38048/jipcb.v8i1.107.

Baka, A., Laksana, D. N. ., \& Dhiu, K. D. (2018). Konten dan konteks budaya lokal Ngada sebagai bahan ajar tematik di Sekolah Dasar. Journal of Education Technology, 2(2), 46-55. https://doi.org/10.23887/jet.v2i2.16181.

Dick, W., \& Carey, J. O. (2009). The systematic design of instruction. Inc.

Divan, S. (2018). Pengembangan Bahan Ajar Tematik Berbasis Budaya Lokal untuk Siswa Kelas IV Sekolah Dasar. Jurnal Kajian Teori Dan Praktik Kependidikan, 3(1), 101-114. http://journal2.um.ac.id/index.php/jktpk/article/view/4433.

Fitriyani, Y., Supriatna, N., \& Sari, M. Z. (2021). Pengembangan Kreativitas Guru dalam Pembelajaran Kreatif pada Mata Pelajaran IPS di Sekolah Dasar. Jurnal Kependidikan: Jurnal Hasil Penelitian Dan Kajian Kepustakaan Di Bidang Pendidikan, Pengajaran Dan Pembelajaran, 7(1), 97. https://doi.org/10.33394/jk.v7i1.3462.

Ghasemi, B., \& Hashemi, M. (2011). Foreign language learning during childhood. Procedia-Social and Behavioral Sciences, 28, 872-876. https://doi.org/10.1016/j.sbspro.2011.11.160.

Gimatdinova, F. (2018a). Benefits of learning a foreign language at an early age. Journal of International Social Research, 11(59), 132-137. https://doi.org/10.17719/jisr.2018.2622.

Gimatdinova, F. (2018b). Benefits of Learning a Foreign Language at An Early Ege. Journal of International Social Research, 11(59), 132-137. https://doi.org/10.17719/jisr.2018.2622.

Hapsari, F., Desnaranti, L., \& Wahyuni, S. (2021). Peran Guru dalam Memotivasi Belajar Siswa selama Kegiatan Pembelajaran Jarak Jauh. Research and Development Journal of Education, 7(1), 193. https://doi.org/10.30998/rdje.v7i1.9254.

Hutama, F. S. (2016). Pengembangan Bahan Ajar Ips Berbasis Nilai Budaya Using Untuk Siswa Sekolah Dasar. JPI (Jurnal Pendidikan Indonesia), 5(2), 113-124. https://doi.org/10.23887/jpi-undiksha.v5i2.8359.

Isnaini, F. N., Krahayon, M. U., Safitri, H. I., \& Lestari, D. (2018). Media Pengenalan Kebudayaan Lokal Berbasis Karakter Untuk Anak Usia Dini. Jurnal Pendidikan Anak, 7(1), 53-60. https://doi.org/10.21831/jpa.v7i1.24445.

Jannah et al. (2021). Efektivitas Penggunaan E-Modul Terhadap Hasil Belajar Kognitif Pada Materi Sistem Pencernaan Manusia di Madrasah Tsanawiyah. Jurnal Basicedu, 5(2), 1060-1066. https://doi.org/10.31004/basicedu.v5i3.952.

Krismawati, N. U. (2019). Pengembangan Bahan Ajar Penulisan Sejarah Berbasis Model Project-Based Learning. Indonesian Journal of Social Science Education (IJSSE), 1(2), 156-170.

Kurniawan, P. Y. (2019). Keefektifan Penggunaan Bahan Ajar Interaktif Yang Berbasis Kearifan Lokal Brebes Dalam Mata Kulia Semantik. BAHASTRA Jurnal Pendidikan Bahasa Dan Sastra Indonesia, 3(2), 170-176. https://jurnal.uisu.ac.id/index.php/Bahastra/article/view/3167.

Laksana, P, K., \& Niftalia, I. (2016). Pengembangan bahan ajar tematik SD kelas IV berbasis kearifan lokal masyarakat Ngada. Jurnal Ilmiah Pendidikan Citra Bakti, 3(1), 1-10. www.ejournal.citrabakti.ac.id/index.php/jipcb/article/view/74/0.

Lawe, Y. ., Dopo, T., \& Kaka, P. . (2019). Pengembangan Bahan Ajar Elektronik Berbasis Budaya Lokal Ngada untuk Pembelajaran Tematik Siswa Sekolah Dasar. Jurnal Ilmiah Pendidikan Citra Bakti, 6(2), 135-145. https://doi.org/10.38048/jipcb.v6i2.38.

Lawe, Y. ., Noge, M. ., Rato, K. P. ., \& Novaliendry, D. (2021). Creation of multilingual teaching materials focused on content and background of Ngada culture for primary 1st grade. Journal of Computer and Mathematics Education, 12(2), 3110-3118. https://doi.org/10.17762/turcomat.v12i2.2355.

Lawe, Y. ., Noge, M. ., Wede, E., \& Itu, I. . (2021). . 0. Penggunaan bahan ajar elektronik multimedia berbasis budaya lokal pada tema daerah tempat tinggalku untuk meningkatkan kemampuan berpikir tingkat tinggi siswa sekolah dasar. , 8(1),. https://doi.org/. Jurnal Ilmiah Pendidikan Citra Bakti, 8(1), 92-102. https://doi.org/10.38048/jipcb.v8i1.104.

Liyana, A., \& Kurniawan, M. (2019). Speaking Pyramid sebagai Media Pembelajaran Kosa Kata Bahasa Inggris Anak Usia 5-6 Tahun. Jurnal Obsesi : Jurnal Pendidikan Anak Usia Dini, 3(1). https://doi.org/10.31004/obsesi.v3i1.178.

Maili, S. . (2018). Bahasa inggris pada sekolah dasar: mengapa perlu dan mengapa dipersoalkan. Jurnal Pendidikan Unsika, 6(1), 23-28. https://journal.unsika.ac.id/index.php/judika/article/view/1203.

Muga, W., \& D.N.L., L. (2017). Pengembangan Bahan Ajar Elektronik Berbasis Model Problem Based Learning Dengan Menggunakan Model Dick And Carey. Journal of Education Technology, 1(4), 260-264. https://doi.org/10.23887/jet.v1i4.12863.

Muhamad Nova. (2017). Character Education In Indonesia EFL Classroom Implementation and Obstacles. Jurnal Pendidikan Karakter, 7(2). https://doi.org/10.21831/jpk.v7i2.13650.

Mustaqim, I., \& Wijayanti, W. (2019). Problematika Penerapan Kurikulum 2013 pada Mata Pelajaran Tematik Madrasah Ibtidaiyah di Kecamatan Jogoroto Jombang. Jurnal Pendidikan Dasar Islam, 1(2), 1-23. http://journal.unipdu.ac.id:8080/index.php/jpdi/article/view/1900. 
Nasution, A. Y., \& Jazuli, M. (2020). Menangkal Degradasi Moral di era Digital bagi kalangan Milenial. Jurnal Pengabdian Dharma Laksana, 3(1), 79-84. https://doi.org/10.32493/j.pdl.v3i1.6304.

Nugrahani, F. (2017). The Development Of Film Based Literary Materials Which Suport Character Education. Jurnal Cakrawala Pendas, XXXVI(3), 472-486. https://doi.org/10.21831/cp.v36i3.14219.

Nuraini, L. (2019). Integrasi Nilai Kearifan Lokal Dalam Pembelajaran Matematika SD/MI Kurikulum 2013. JURNAL PENDIDIKAN MATEMATIKA (KUDUS), 1(2). https://doi.org/10.21043/jpm.v1i2.4873.

Onde, M. L. ode, Aswat, H., Fitriani, \& Sari, E. R. (2020). Integrasi Penguatan Pendidikan Karakter (PPK) ERA 4.0 Pada Pembelajaran Berbasis Tematik Integratif Di Sekolah Dasar. Jurnal Basicedu, 4(2), 268-279. https://doi.org/10.31004/basicedu.v4i2.321.

Pitaloka, D. L., Dimyati, D., \& Edi, P. (2021). Peran Guru dalam Menanamkan Nilai Toleransi pada Anak Usia Dini di Indonesia. Jurnal Obsesi: Jurnal Pendidikan Anak Usia Dini, 5(2), 1696-1705. https://doi.org/10.31004/obsesi.v5i2.972.

Prayogi, D. S., Utaya, S., \& Sumarmi, S. (2019). Internalisasi Kearifan Lokal Dalam Pembelajaran melalui Pengembangan Multimedia Interaktif Muatan Pembelajaran IPS. Jurnal Pendidikan: Teori, Penelitian, Dan Pengembangan, 4(11), 1457-1463.

Priyastuti, M. T., Resanti, M., \& Yoga, G. S. (2020). Peningkatan Kosakata Bahasa Inggris dengan Media Ular Tangga bagi Siswa SD Antonius 2 Semarang. Abdimasku: Jurnal Pengabdian Masyarakat, 3(2), 72. https://doi.org/10.33633/ja.v3i2.106.

Putra, K. W. B., Wirawan, I. M. A., \& Pradnyana, G. A. (2017). Pengembangan E-Modul Berbasis Model Pembelajaran Discovery Learning Pada Mata Pelajaran “ Sistem Komputer " Untuk Siswa Kelas X Multimedia Smk Negeri 3 Singaraja. Jurnal Pendidikan Teknologi Dan Kejuruan, 14(1), 40-49. https://doi.org/10.23887/jptk.v14i1.9880.

Rahman, E. S., Sari, T. T., \& Meita, N. M. (2019). Pengembangan Buku Saku Tematik Sd Berbasis Kearifan Budaya Lokal. Jurnal Pendidikan Dasar, 3(2), 70-78. https://doi.org/10.24929/alpen.v3i2.28.

Riwu, I. U., Laksana, D. N. ., \& Dhiu, K. . (2018). Pengembangan bahan ajar elektronik bermuatan multimedia pada tema peduli terhadap makhluk hidup untuk siswa sekolah dasar kelas IV di Kabupaten Ngada. Journal of Education Technology, 2(2), 56-64. https://doi.org/10.23887/jet.v2i2.16182.

Rizki, S., \& Linuhung, N. (2017). Pengembangan Bahan Ajar Program Linear Berbasis Kontekstual Dan Ict. AKSIOMA Journal of Mathematics Education, 5(2), 137-144. https://doi.org/10.24127/ajpm.v5i2.674.

Saidah, N., Parmin, \& Dewi, N. R. (2014). Pengembangan LKS IPA Terpadu Berbasis Problem Based Learning Melalui Lesson Study Tema Ekosistem Dan Pelestarian Lingkungan. USEJ - Unnes Science Education Journal, 3(2). https://doi.org/10.15294/usej.v3i2.3357.

Sarini, P., \& Selamet, K. (2019). Pengembangan Bahan Ajar Etnosains Bali bagi Calon Guru IPA. Jurnal Matematika,Sains, Dan Pembelajarannya, 13(1), 27-39.

Setyowati, N., \& Mawardi, M. (2018). Sinergi Project Based Learning dan Pembelajaran Bermakna untuk Meningkatkan Hasil Belajar Matematika. Scholaria: Jurnal Pendidikan Dan Kebudayaan, 8(3), 253-263. https://doi.org/10.24246/j.js.2018.v8.i3.p253-263.

Subhan, A., Untirta, P., \& Pamungkas, A. S. (2017). Pengembangan Bahan Ajar Berbasis. Jurnal Bioedukatika, 8(1), 72-82.

Sudarsana, I. K. (2016). Peningkatan mutu pendidikan luar sekolah dalam upayapembangunan sumber daya manusia. Jurnal Penjaminan Mutu, $1(1), \quad 14$. http://www.ejournal.ihdn.ac.id/index.php/JPM/article/download/34/43.

Sudrajat, C. J., Agustin, M., Kurniati, L., \& Karsa, D. (2021). Strategi Kepala TK dalam Meningkatkan Mutu Pendidikan pada Masa Pandemi Covid 19. Jurnal Obsesi : Jurnal Pendidikan Anak Usia Dini, 5(1), 508-520. https://doi.org/10.31004/obsesi.v5i1.582.

Suplemen, P., Ajar, B., Berbasis, B., \& Identifikasi, R. (2017). Pengembangan Suplemen Bahan Ajar Biologi Berbasis Riset Identifikasi Bakteri untuk Siswa SMA. Journal of Innovative Science Education, 6(2), 155161. https://doi.org/10.15294/jise.v6i2.19713.

Supramono, A. (2016). Pengaruh model pembelajaran quantum (quantum teaching) terhadap hasil belajar IPA siswa kelas III SD YPS Lawewu kecamatan Nuha kabupaten Luwu Timur. Jurnal Nalar Pendidikan, 4, 367-375. 